\title{
Pathological Manifestations on Concrete Bridges at Recife's Metropolitan Area
}

Eudes de Arimatéa Rocha ${ }^{1}$, Felipe José Salomão de Albuquerque Melo ${ }^{1}$, Severino Virgílio Silva ${ }^{1}$, Eliana Cristina Barreto Monteiro ${ }^{1,2}$ and Rafaella Gatis Galvão ${ }^{1}$

1. Department of Civil Engineering, University of Pernambuco, Recife 50720001 , Brazil

2. Department of Civil Engineering, Catholic University of Pernambuco, Recife 50050 900, Brazil

\begin{abstract}
Bridges are structures being used to cross rivers, lakes or any other obstacles which involve water. These instruments are commonly used in cities like Recife, which consists of several islands. However, it is common in this city to observe the fast deterioration of these structures that have been built for decades and are subjected to structural recoveries only when they present a possible imminent collapse. The maintenance of these constructions, often used as tourist spots, is essential because of the economic importance, while these structures are responsible for transporting people and cargo, and also play a key role in the city's roads. This paper aims to present and assess the conservation status of these bridges through the study of possible pathologies found at Princesa Isabel Bridge, Government Agamenon Bridge, Ponte Giratória Bridge and Paulo Guerra Bridge. The methodology for its inspection will be prescribed by ABNT NBR-9452/86, which provides for "Surveys of Concrete Bridges/Viaducts". After analysis, it was found that most bridges problems were caused by the presence of moisture that accumulates in bridges due to the absence or malfunction of drainage systems.
\end{abstract}

Key words: Bridge, maintenance, pathological manifestations.

\section{Introduction}

Bridges are often set across rivers, lakes or any other obstacles which involve water [1]. These instruments are commonly used in cities like Recife (Pernambuco, Brazil), which consists of several islands in waters. And it is also common in this city to observe the fast deterioration of these structures, with pathological manifestations that can be seen by just looking at them, which have been built for decades and are subjected to structural recoveries only when they present a possible imminent breakdown.

Lack of federal, state and municipal agencies policies and strategies, aimed at maintaining public works, also contributes to the degradation of most works, like bridges and viaducts that comprise the Brazilian road network and are part of the group of structures with difficult access to carry out the

Corresponding author: Felipe José Salomão de Albuquerque Melo, M.Sc. candidate, civil engineer, research field: pathology of concrete. E-mail: fjsalomao@gmail.com. inspection, hindering the creation of this previous maintenance policy $[2,3]$.

The situation is worst on older bridges cases, which were designed to support lighter loads compared with today's vehicles'. Thus, this research aims to evaluate and diagnose the possible pathological manifestations found at five bridges located at different aggressiveness areas in Recife, contributing to make a change about the lack of maintenance custom.

\section{Methodology for Inspection}

In Brazil, bridges surveys should be done according to ABNT NBR 9452/12-Concrete Bridges and Viaducts Surveys Proceedings [4]. According to Vitório [5], special works surveys must consist these following steps: local examination or visual inspection, original design or modifications analysis, and final report if it is necessary.

Bridge inspection should be conducted in a systematic and organized way to ensure that all structural elements 
are inspected. In this sense, inspection records were created to register inspected bridges and ensure that no element was left out of the inspection.

This work execution methodology still follows the inspection methodology model applied to various reinforced concrete structures and initially used by Castro [6]. This method is based on a concrete structures routine of maintenance and search for complete understanding of the pathological manifestations which were found. The main steps are described below:

(1) preliminary inspection-all structures visual inspection, by doing a data collection, recording and photographing all visual symptoms;

(2) detailed inspection-deterioration extent or structure damage determination;

(3) obtained data analysis - step performed in detail to prevent most severe abnormalities which were not detected;

(4) diagnostics - step that shows the study results of the pathological manifestations in order to initiate studies about possible alternatives that could solve the presented problems.

The determination of which bridges would be studied was made by these following criteria: the bridge historicity and location, the vehicles flow passing over the bridge, the ease access for doing a visual inspection and the lack of maintenance time.

\section{Results}

The inspected bridges were the main bridges at Recife, Pernambuco: Princesa Isabel Bridge, Governador Agamemnon Magalhães Bridge, Antiga Ponte Giratória Bridge and Paulo Guerra Bridge. Finally, the bridge located at Aldeia Road, Camaragibe was also studied. The results found during the survey are presented separately below.

\subsection{Princesa Isabel Bridge}

With 98 years of existence, Princesa Isabel Bridge is a reinforced concrete structure with board grid and nine continuous beams. It has $139.50 \mathrm{~m}$ of extension, divided into two extremes interspaces of $24.85 \mathrm{~m}$ and three intermediate ones of $29.95 \mathrm{~m}$. These interspaces are bi-clamped arches. They are supported by pillars, above a support apparatus and subsequent deep foundation type.

When the structure was observed that it does not present a drainage system, which promotes generalized infiltration, the main problems found at Princesa Isabel Bridge were:

- efflorescence, probably caused by water penetration through the slab, since the presence of moisture was observed, as shown in Fig. 1;

- cracks, reinforcement exposure and corrosion, and concrete deterioration (Fig. 2). The reinforcement corrosion is a major problem that affects most reinforced concrete buildings, either by contamination

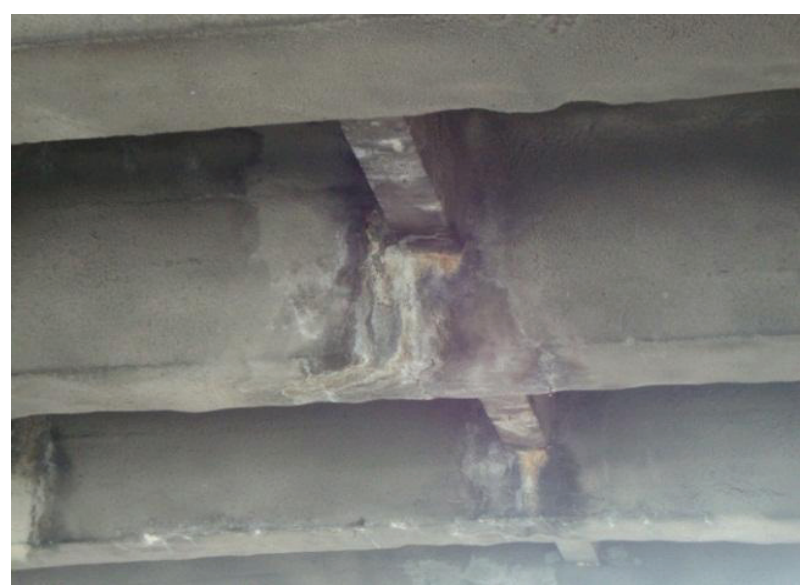

Fig. 1 Damp and efflorescence on crossbeams and girders. Source: the authors.

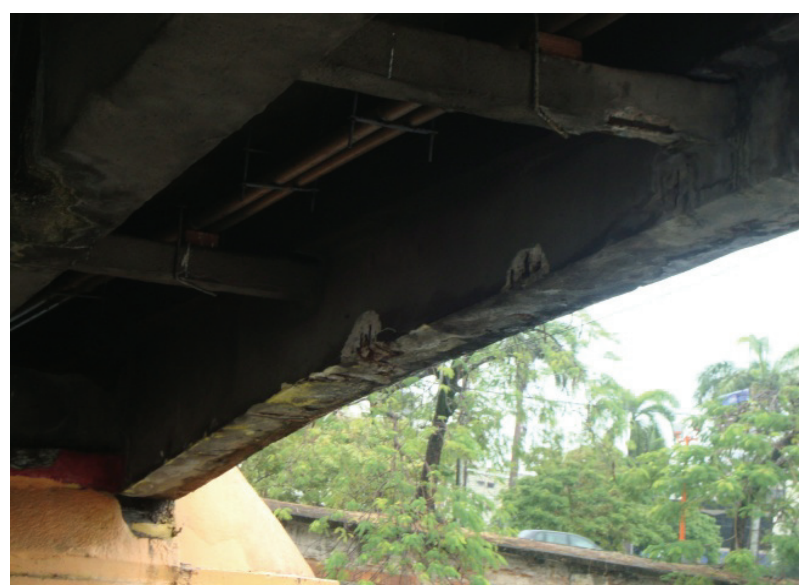

Fig. 2 Concrete deterioration, and beams reinforcement exposure and corrosion.

Source: the authors. 
during the execution over the years, because it deteriorates the concrete, allowing agents penetration causing corrosion.

\subsection{Governador Agamenon Magalhães Bridge}

The Governador Agamenom Magalhães Bridge, commonly known as the "Pina Bridge", is also located at a very aggressive zone. It is 58 years old and has gone through repair services. However, during the investigation, the need for an intervention to recover the structural elements, especially some parts of the arches supports that are subjected to tidal movements and have reinforcement exposure as shown in Fig. 3, is needed.

The structure has a drainage system, but they are obstructed in some sections, which causes leakage mainly at crossbeams that also can be seen in Fig. 3 .

\subsection{Antiga Ponte Giratória Bridge}

Despite that it was inaugurated as 12 de Setembro Bridge, people referred to it as Ponte Giratória Bridge. Probably because of this, through Law No. 16916 of November 19, 2003, its name was changed to Antiga Ponte Giratória Bridge.

During the inspection, it was observed that Antiga Ponte Giratória Bridge has two independent structures: One is the prestressed concrete and another the coffin cell type, which is probably the old iron bridge construction road remnant, as shown in Fig. 4.

In mid-2007, sidewalk slab facing north fell because of the high state of deterioration. In virtue of this event, Recife City Council decided to remove the entire northbound slab (Fig. 5), leaving only a ride with railing on the south side of the bridge.

During the survey, several pathological manifestations and construction faults are found:

- small nominal coating;

- armor exposed indicating pitting corrosion;

- generalized infiltration, caused by blockage of drains and no drip pans.

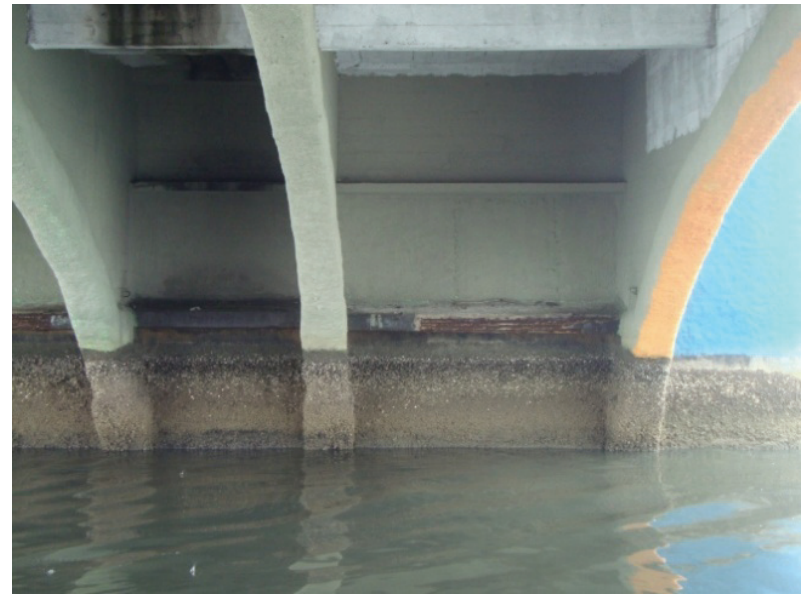

Fig. 3 Moisture patches on the crossbeams and reinforcement exposed in a high state of corrosion on the bases of support.

Source: the authors.

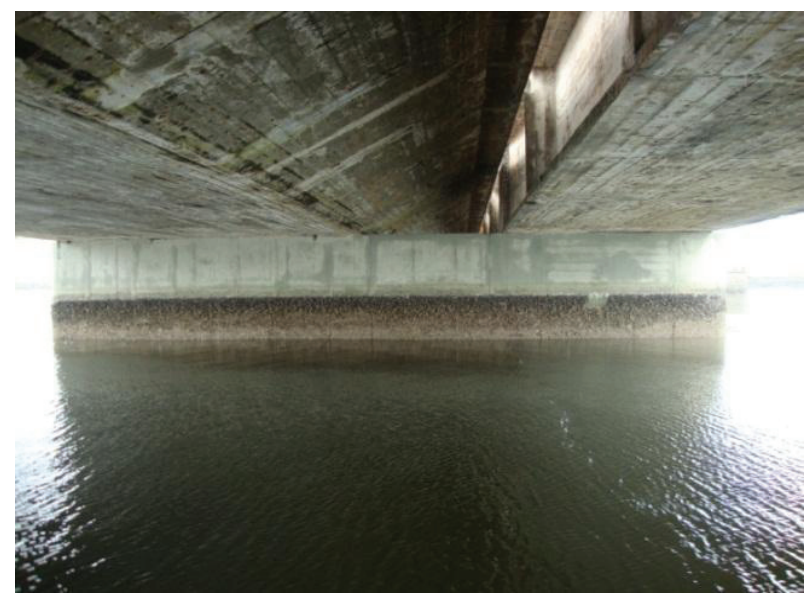

Fig. 4 Antiga Ponte Giratória Brdge's independent structures.

Source: the authors.

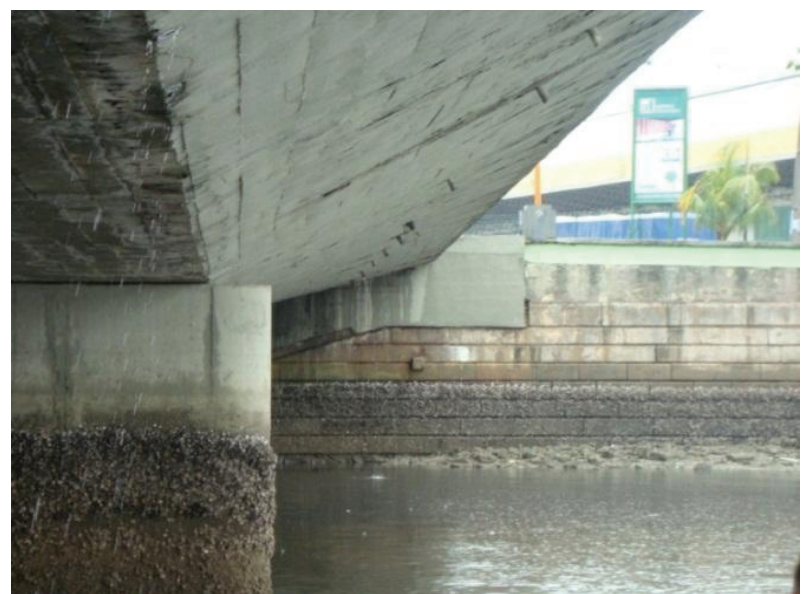

Fig. 5 Modification of the structure-removal of the slab ride due to partial collapse.

Source: the authors. 
It is important to note the need of efficient drainage bridges, considering the problems severity caused by the presence of moisture in the structure (steel corrosion, infiltration, leaching, etc.). In this sense, the drains and drip pans are important tools to prevent the action of water in the structure. Figs. 6 and 7 show the bridge problems because of the moistures presence.

\subsection{Paulo Guerra Bridge}

Built in 1978, Paulo Guerra Bridge is an important access route between the districts of Boa Viagem and Recife commercial center. In mid-2005, the bridge, $460 \mathrm{~m}$ long, received structural recovery on supports, repairs on expansion joints and guardrails and support equipment exchange. It also got the asphalt resurfacing and signaling paint redone.

During the bridge inspection, irregularity was found only in relation to drainage. Next to the drains, there were infiltration spots, proving the inefficiency drains that were clogged or poorly dimensioned, as shown in Fig. 8.

\subsection{Aldeia Bridge}

This bridge dates from the 1950s and is located at a different aggressive area from the studied other ones. It has a structure of a single bi-supported span, without rocking, which acts as a rigid gantry.

The pillars foundations are concrete piles, which are completely buried. According to the surveys, the soils are basically composed of organic clay, thus justifying the use of stakes. There is also a containment structure, called "wing", which is used as hydrology containment barrier and also for the lateral containment landfill. The structure foundation is the direct type.

The wing structure is tumbling, as shown in Fig. 9, due to the lack of river drainage and bottom shoes pullout probably caused by the flow of the river.

The meso-structured structural parts, since there are no neoprene type support equipments, work as a hard porch and their meetings are of reinforced concrete with no drainage, which promotes the widespread infiltration into the tops of the support. This probably comes from rainwater infiltration accumulated into ground due to lack of drainage. Fig. 10 shows

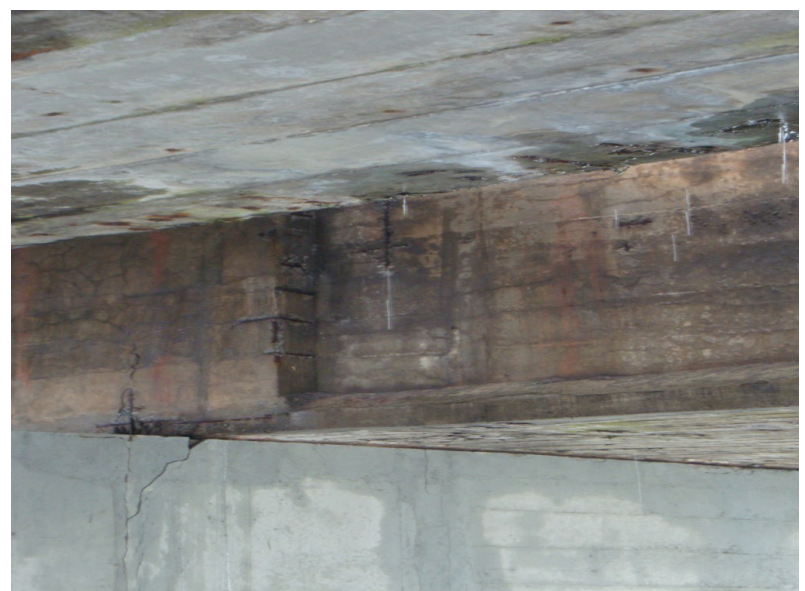

Fig. 6 Moisture stains and reinforcement corrosion on both structures and cracks on foundations banking.

Source: the authors.

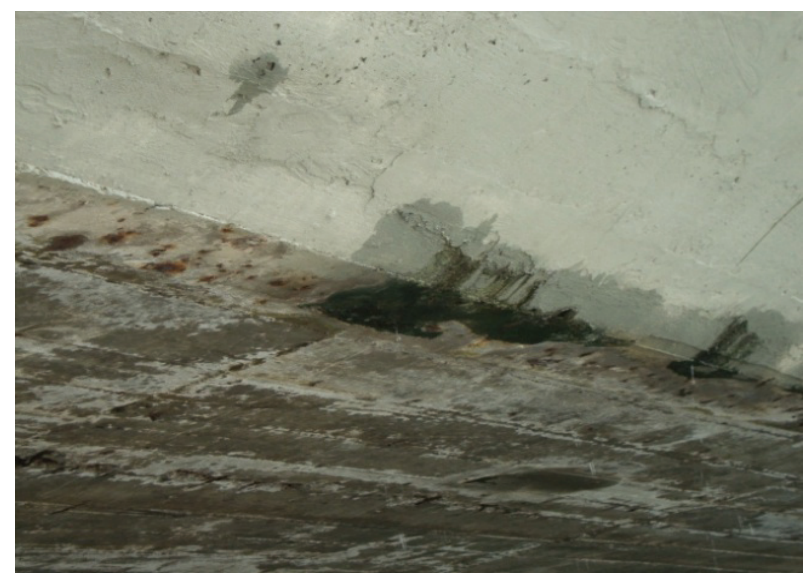

Fig. 7 Water infiltration and accumulation in coffin cell structure.

Source: the authors.

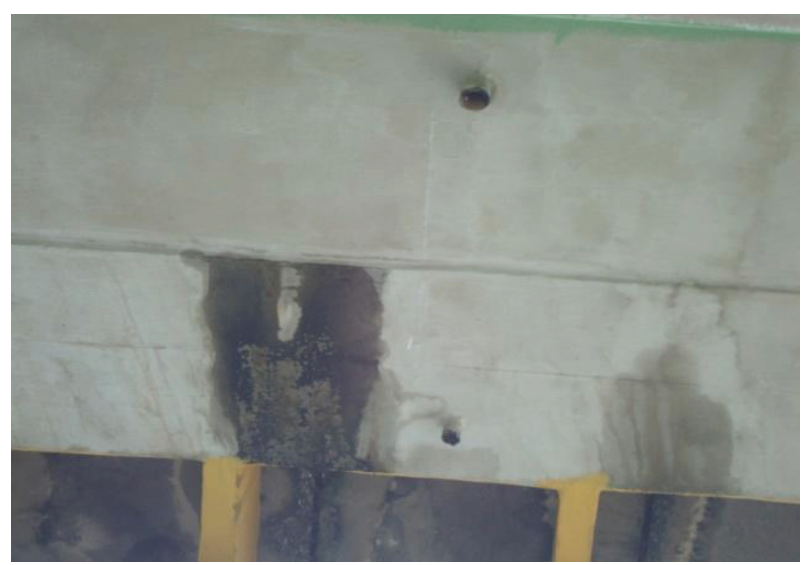

Fig. 8 Clogged drains and infiltration patches. Source: the authors. 


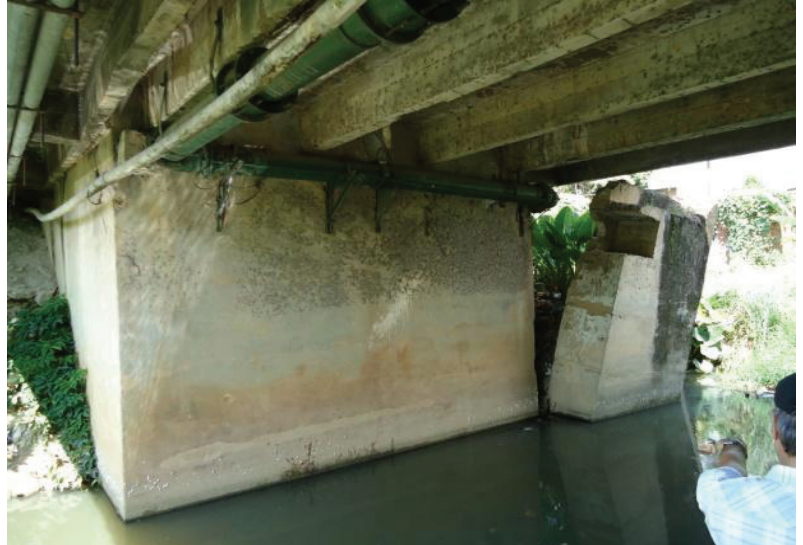

Fig. 9 Wing structure tipping process.

Source: the authors.

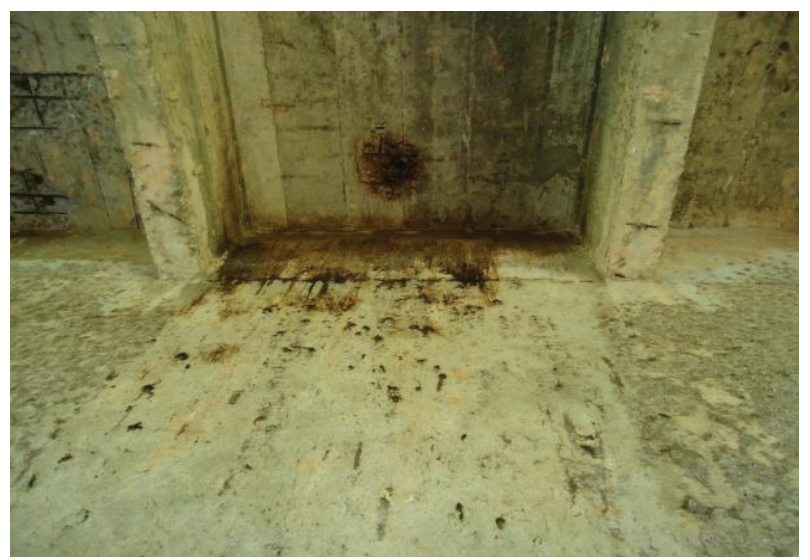

Fig. 10 Armour exhibition and widespread infiltration of the structure.

Source: the authors.

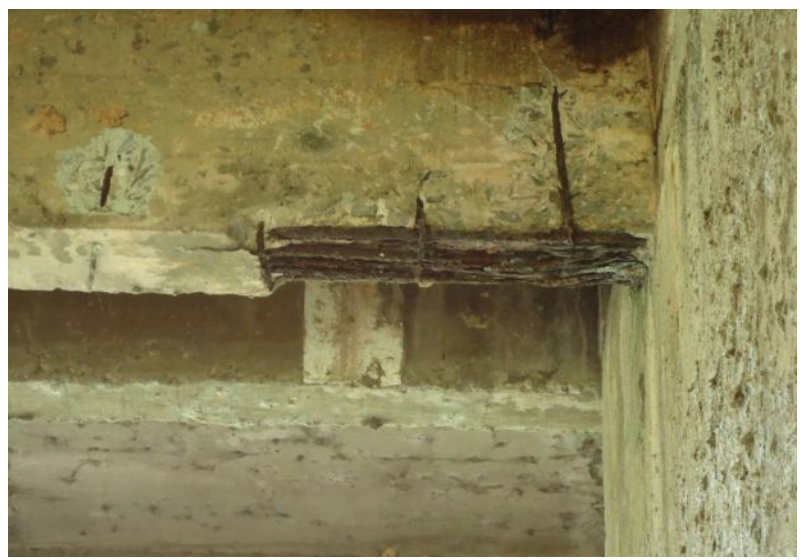

Fig. 11 The reinforcement corrosion in the central portion of the stringer with the rupture of the stirrups and loss of steel section.

Source: the authors.

reddish-brown points, indicating water and high probability of reinforcement corrosion on these structures.
The tracks consist of four stringers, all supported by two beams. They have many pathological manifestations, among which cracks, deformations, malformation concrete, exposure and reinforcement corrosion and concrete deterioration (Fig. 11) may be mentioned.

Central slabs are also in very precarious situation. Due to rainwater accumulation and a very porous concrete, many slab reinforcement sections are exposed and corroded. Irregular coatings values ranging from $1 \mathrm{~cm}$ to $2 \mathrm{~cm}$, measured at various sections.

Another pathological manifestation found on slabs is the presence of leaching and efflorescence in the sections of the slabs near meetings, including stalactites formation and indicating a drag area of concrete material components.

\section{Concluding Remarks}

As previously mentioned, Recife has a large number of bridges, especially when considering the entire metropolitan area. In all, supervised and inspected five bridges located in the Metropolitan Region of Recife were supervised. And after the application of a checklist, a database of collected data that provides information for the preparation of the chart established.

As can be seen by examining Fig. 12, the most pathological manifestation is the presence of moisture and infiltration. The moisture is a factor which permits the development of other problems in the structure, because it makes the environment favorable to penetration of other aggressive agents, such as reinforcement corrosion and leaching of cement materials components and consequent early appearance of efflorescence and strength weakening [7].

Another considered factor is the presence of drainage systems in inspected bridges. Fig. 13 indicates that, in all bridges inspected, only $13 \%$ bridges have drainage and drip pans operating system, 37\% ones have no drainage and $50 \%$ of the bridges have the mechanisms drain clogged or in a wrong size. 


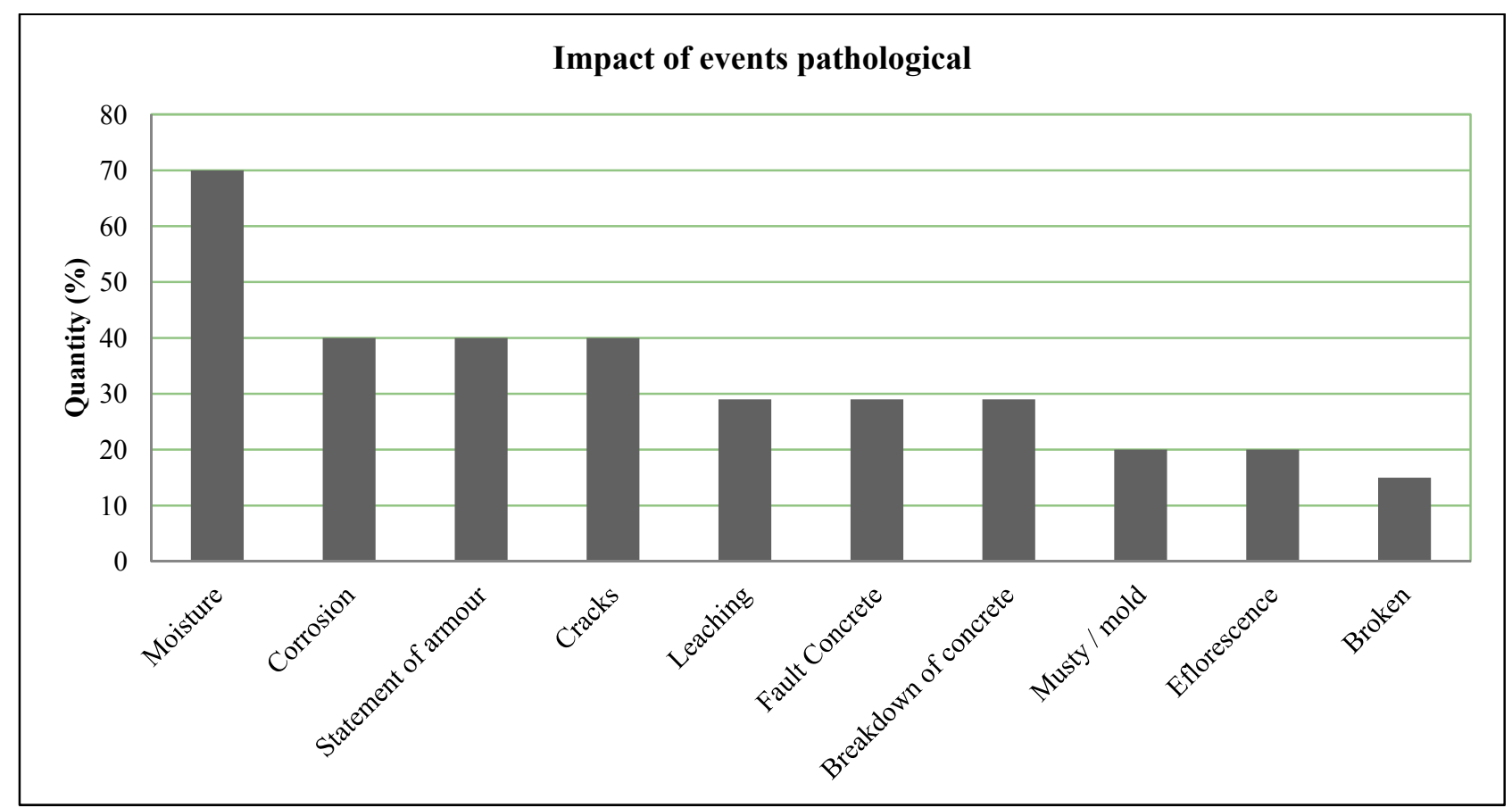

Fig. 12 Effect of pathological manifestations on bridges in the metropolitan region of Recife.

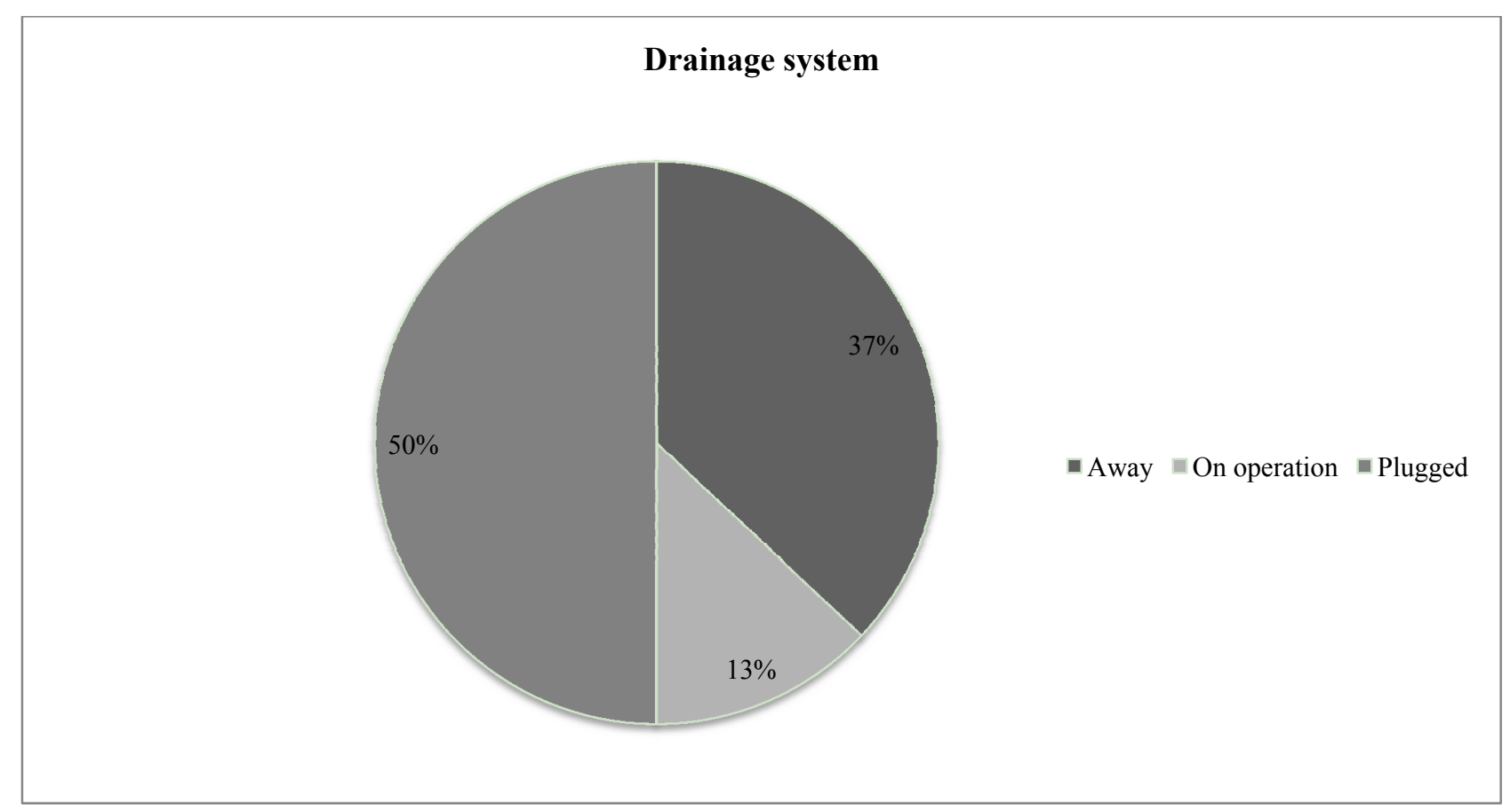

Fig. 13 Drainage system inspected bridges.

This completes the given reason for the metropolitan region of Recife in which bridges are more subject to the action of moisture, since no drainage works, and stormwater accumulates in structures promoting a favorable environment for other pathogens proliferation.

In greater details on the comments of the inspected bridges, they present the following specific considerations for the diagnosis of each evaluated bridge. 
For Antiga Ponte Giratória Bridge, whose conservation status is precarious, it calls up the general recovery of the superstructure of the bridge and it is advisable:

- the drains clearing and construction of drip pans to stop the water retention, avoiding problems like infiltration spots, leaching of material cement components and reinforcement corrosion;

- increasing nominal coatings of entire superstructure, since it is leased a very high environmental aggression zone and according to the NBR-6118 (2014) [8], the structural parts of the coating should be at least $4.00 \mathrm{~cm}$;

- recovering the armor slabs, replacing those with loss of section and using shotcrete to create a new layer of concrete, thus increasing the thickness of the concrete cover of the reinforcement;

- consulting an expert engineer to ascertain the need for a strengthening of structural components.

For Paulo Guerra Bridge, despite having gone through a recent process of structural recovery, it needs constant monitoring since this bridge is being expanded by alkali aggregate reaction. Besides monitoring, to unblock some drains is also recommended.

For Governador Agamenon Magalhães Bridge, although it does not present a lot of pathological manifestations, it needs some local repairs and requires a deeper investigation of the storage conditions of the bridge. For this bridge, it was suggested:

- restoration of the support reinforcements, since they are exposed to the action of tidal variations;

- consulting an expert to size drains and drip pans to avoid widespread infiltration.

Princesa Isabel Bridge has a high state of structure degradation, requiring immediate intervention. Accordingly, the following points are recommended:

- the recovery of stringers and crossbeams armors, replacing those with loss of section and hire a specialized calculating engineer to strengthen these structural parts;
- waterproofing the central board in order to stop the infiltration and consequently leaching and efflorescence, particularly in the crossbeams;

- unclogging drains and building drip pans to prevent rainwater accumulation;

- repairing holes which were made for fixing pipes with shotcrete, reducing the penetration of aggressive agents in the structure.

Regarding Aldeia Bridge, the wings erosion and tumbling were caused by foundation problems because of the change of the river course. The changing course of the river was probably caused by the lack of drainage and accumulation of garbage along the river. Oxidation of armor found in this bridge may have been caused by the presence of moisture and the large amount of porous concrete structure that facilitates the aggressive agents penetration. The presence of moisture in the structure can be explained again by the absence of stormwater drainage system in the central board.

It is assumed that the rainwater infiltrates into ground by the end of the encounter between the roadway of the bridge and approach lanes and by capping the openings in walking belt area. This theory is justified by the location of reinforcement corrosion, which lies close to the crossbeams and, at some points, locates at the bottom of the slab.

According to what was presented by the precarious state of conservation and because of the high request of cars to which Aldeia Bridge is subjected, it is recommended the following interventions:

- making a drainage and cleaning of the river, so that there is no more deposition and accumulation of materials on the river banks;

- construction of check dams downstream the river to try to restore the previous flow of the river and performing monitoring of these procedures;

- consulting a qualified engineer to undertake the recovery ward of the foundation that is tumbling;

- performing cleaning of landfills and creating a new containment system of land (for this case, the use 
of geomembranes or land-armed is indicated), seeking to recover the wings showing erosion and overturning process;

- recovering the stringers and crossbeams armors, replacing those with loss of section and hiring a specialized calculating engineer to strengthen these structural parts;

- recovering the slabs armor, replacing those with loss of section and using shotcrete to create a new layer of concrete, thus increasing the thickness of the concrete cover of the reinforcement;

- repairing holes made for fixing pipes with shotcrete and reducing the penetration of aggressive agents in the structure;

- constructing drains and drip pans to drain rainwater away from the structure to avoid future leaks;

- performing minor repairs guardrails located on the left side of the bridge under study;

- resurfacing sections of the rolling road that have openings, so that traffic can flow freely in this region.

It is believed that these procedures can correct the problems found in the inspected bridges, extending the life of the structure and ensuring its functioning for a longer time.

The importance of the awareness of companies and businesses of installing water pipes, gas and mains electric should be stressed, so there is a greater commitment towards conserving the bridges and overpasses during the performance of their services.

\section{Final Conclusions}

Based on the above, it can be said that the most appropriate option to prevent the observed pathological manifestations is focused on prevention and constant inspection of structures, with the goal being to create the preventive maintenance routine. In this regard, it is essential to stress that preventive activity should be started with the careful preparation of the project of a work of special art, as well as proper implementation with efficient monitoring of services.

At the design stage, it is important to think about the ease of a possible maintenance service, in this case, adding support for lifting devices is a good suggestion. Drains and drip pans should be designed so that there is no accumulation of water in the structure and, in case of any obstructions, there is an emergency drain.

It is worth noting that much of the pathological problems found, such as cracks, corrosion of armor and efflorescence could have been avoided if the humidity was not present in the structure. That is, if the drains and drip pans were in operation, most of the problems could have been avoided.

The importance of the awareness of companies and businesses of installing water pipes, gas and mains electric should be stressed, so there is a greater commitment towards conserving the bridges and overpasses during the performance of their services.

Finally, it is recommended to recover the inspected structures and the accompaniment in order to avoid the proliferation of new pathological manifestations.

\section{Acknowledgments}

The authors would like to thank the POLI-UPE (Politechnic School of Pernambuco University), the PROCAD/NF and CAPES (Higher Education Personnel Training Coordination) for financial support on this research.

\section{References}

[1] Marchetti, O. 2008. Concrete Bridges. São Paulo: Blucher.

[2] Giovannetti, A. C. V. P. $2014 . \quad$ "Bridge Assessment-Case Study." Master thesis, Federal University of Santa Catarina.

[3] Vitório, J. A. P, and Barros, R. M. M. C. 2013. “Analysis of Structural Damage and Stability Conditions of 100 Road Bridges in Brazil." Presented at Congress Portuguese Association for Safety and Conservation of Bridges, Porto.

[4] ABNT. 2012. NBR 9452: Vistorias de Pontes e Viadutos de Concreto (Inspections of Bridges and Concrete Viaducts). Rio de Janeiro: ABNT. (in Portuguese)

[5] Vitório, J. A. F. 2002. Pontes Rodoviárias: Fundamentos, 
Conservação e Gestão (Road Bridges: Fundamentals, Conservation and Management). Recife: CREA-PE. (in Portuguese)

[6] Castro, E. K. 1994. "Desenvolvimento de Metodologia Para Manutenção de Estruturas de Concreto Armado." Dissertação de Mestrado (Methodology Development for Maintenance the Structures Concrete Armed)." Master thesis, University of Brasilia. (in Portuguese)

[7] Pannoni, F. D. 2009. Projeto e Durabilidade (Project and
Durability). Rio de Janeiro: Instituto Brasileiro de Siderurgia-Centro Brasileiro da Construção em Aço (Brazilian Steel Institute-Brazilian Center Steel Construction). (in Portuguese)

[8] ABNT (Brazilian Association of Technical Standards). 2014. NBR 6118: Projeto de Estruturas de Concreto-Procedimento (Concrete Structures Design-Procedure). Rio de Janeiro: ABNT. (in Portuguese) 